\title{
NEODYMIUM AND STRONTIUM ISOTOPIC CONSTRAINTS ON THE ORIGIN OF THE PERALUMINOUS GRANITOIDS OF THE SOUTH MOUNTAIN BATHOLITH, NOVA SCOTIA, CANADA
}

\author{
D.B. CLARKE ${ }^{1}$, A.N. HALLIDAY ${ }^{2}$ and P.J. HAMILTON ${ }^{3}$ \\ ${ }^{1}$ Department of Geology, Dalhousie University, Halifax, N.S. B3H 3J5 (Canada) \\ ${ }^{2}$ Department of Geological Sciences, University of Michigan, Ann Arbor, MI 48109 (U.S.A.) \\ ${ }^{3}$ Isotope Geology Unit, Scottish Universities Research and Reactor Centre, East Kilbride, \\ Glasgow, G75 0QU (Great Britain)
}

(Received August 26, 1987; revised and accepted March 14, 1988)

\begin{abstract}
Clarke, D.B., Halliday, A.N. and Hamilton, P.J., 1988. Neodymium and strontium isotopic constraints on the origin of the peraluminous granitoids of the South Mountain batholith, Nova Scotia, Canada. Chem. Geol. (Isot. Geosci. Sect.), 73: 15-24.

$\mathrm{Nd}$ isotopic data from the South Mountain batholith show that its peraluminous granitic rocks have considerably higher $\epsilon_{\mathrm{Nd}}^{t}(t=372 \mathrm{Ma})$ values $(-5.2$ to -1.4$)$ than the extensive flyschoid country rocks $(-11.2$ to -8.7$)$. These isotopic data are combined with $\mathrm{Sr}$ isotopic measurements to estimate the involvement of the country rocks, either as source materials or as contaminants, in the batholith. Metasedimentary enclaves in the batholith generally have $\mathrm{Nd}$ and $\mathrm{Sr}$ isotopic compositions intermediate between those of the batholith and the country rocks, and provide evidence of contamination by the country rocks. Integrated with other geochemical data, the isotopic results show at least two possible origins for the South Mountain batholith: either this large hatholith is a hybrid of mantle and crustal materials and contains a large proportion of mantle-derived $\mathrm{Nd}$ and $\mathrm{Sr}$, or the magma is derived from deeper metasedimentary crustal material, with younger model ages or higher $\mathrm{Sm} / \mathrm{Nd}$ ratios than the upper crust.
\end{abstract}

\section{Introduction}

The granites and country rocks of the Meguma Zone of the northeastern Appalachians have been the object of considerable attention in recent years (McKenzie and Clarke, 1975; Clarke and Halliday, 1980, 1985; Muecke and Clarke, 1981; Keppie and Poole, 1984; Clarke and Muecke, 1985). Briefly, this lithotectonic zone consists of an extensive $\left(125,000 \mathrm{~km}^{2}\right)$, thick ( $>14 \mathrm{~km}$ ) suspect terrane of CambroOrdovician turbidite flysch (Schenk, 1978) that was deformed and metamorphosed in the early
Devonian and intruded by many peraluminous granitoid plutons in the late Devonian-early Carboniferous (Fig. 1) (Clarke and Halliday, 1980; Reynolds et al., 1981, 1987).

The granitoid rocks are characterized by modal andalusite, cordierite, and garnet, and by $A / C N K\left[\mathrm{~mol} \mathrm{Al}_{2} \mathrm{O}_{3} /\left(\mathrm{CaO}+\mathrm{Na}_{2} \mathrm{O}+\mathrm{K}_{2} \mathrm{O}\right)\right] \mathrm{ra}-$ tios $>1$ and, therefore, it might be reasonable to infer some genetic link between them and their enclosing flyschoid rocks, i.e. that they may be typical so-called "S-type" (Chappell, 1984 ) granitoids derived from deeper levels of the thick flyschoid sequence. The present work 


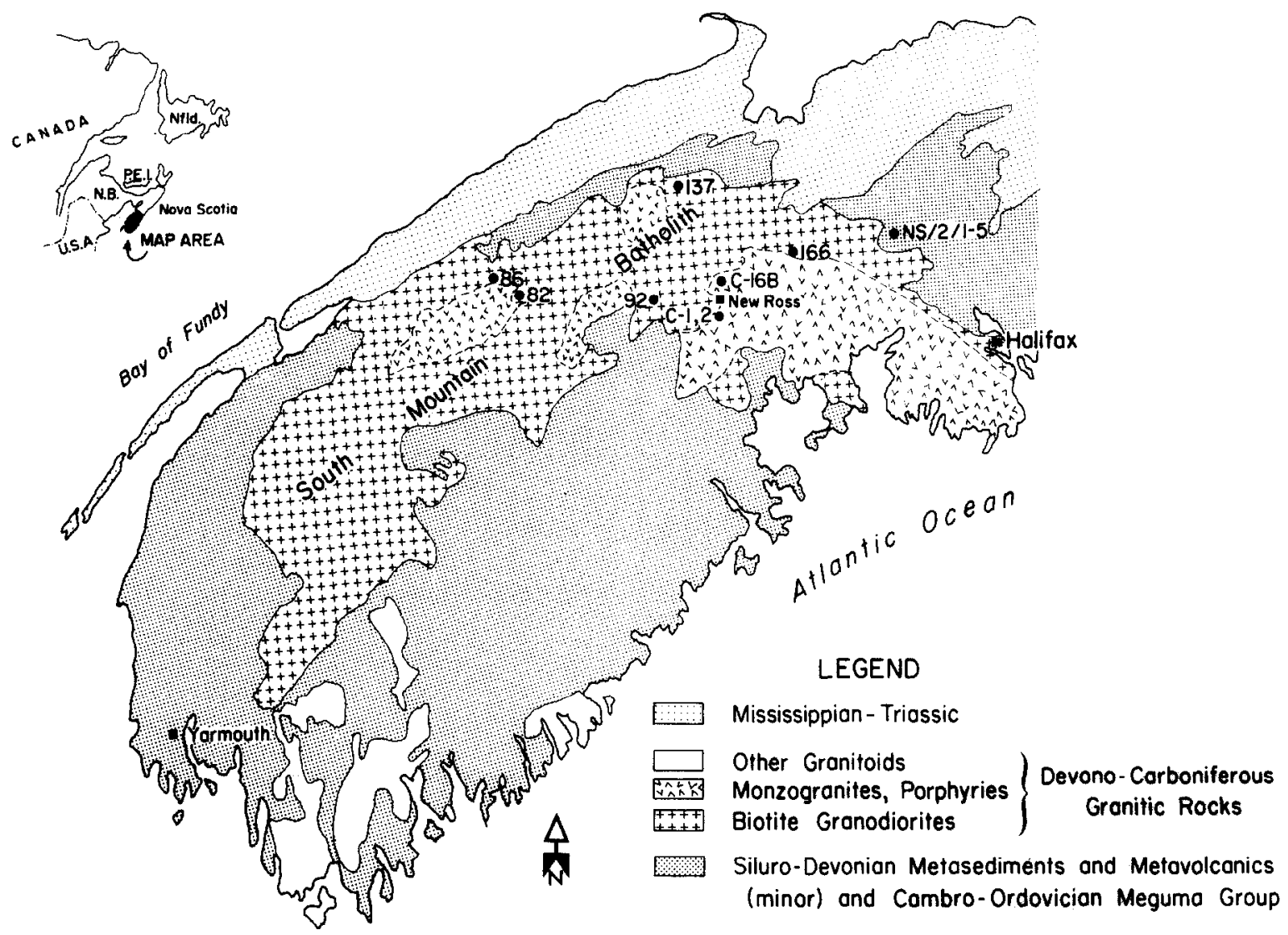

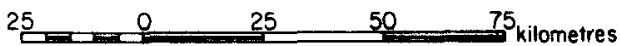

Fig. 1. Simplified geological map of the South Mountain batholith showing location of samples used in this study.

has been undertaken to examine this possible genetic link between the Meguma Zone peraluminous granitoids and their enclosing flysch, to determine the model ages of the granitoids, and to refine the models for the origin and evolution of the largest of the granitic bodies, the South Mountain batholith (SMB).

\section{Analytical techniques and data}

\subsection{Analytical techniques}

$\mathrm{Rb}, \mathrm{Sr}, \mathrm{Sm}$ and $\mathrm{Nd}$ concentrations were determined by isotopic dilution techniques. Analyses were performed on an automated V.G. Isomass ${ }^{\circledR}$ 54E mass spectrometer and all details of the procedures and calibration data have been reported previously (Halliday et al., 1984; Clarke and Halliday, 1985).

\subsection{Data}

Samples used in this investigation were selected from the same group as those examined by Clarke and Halliday (1980) in their study of the $\mathrm{Rb}-\mathrm{Sr}$ whole-rock isochron ages of the several lithological facies of the SMB. From field relations and $\mathrm{Rb}-\mathrm{Sr}$ dating, the sequence of intrusion is: granodiorite $(372 \pm 2 \mathrm{Ma})$ - monzogranite $(364 \pm 1 \mathrm{Ma})$-monzogranite porphyry $(361 \pm 1 \mathrm{Ma})$, with corresponding variations in mean $A / C N K(1.09,1.15,1.20)$, and ${ }^{87} \mathrm{Sr} /{ }^{86} \mathrm{Sr}_{\mathrm{i}}$ $(0.7081,0.7094 \pm 0.0004,0.7102 \pm 0.0012)$. Table I shows that there is also significant variation in $\epsilon_{\mathrm{Nd}}^{t}(-2.2,-3.3,-5.1)(t=372,364$, 


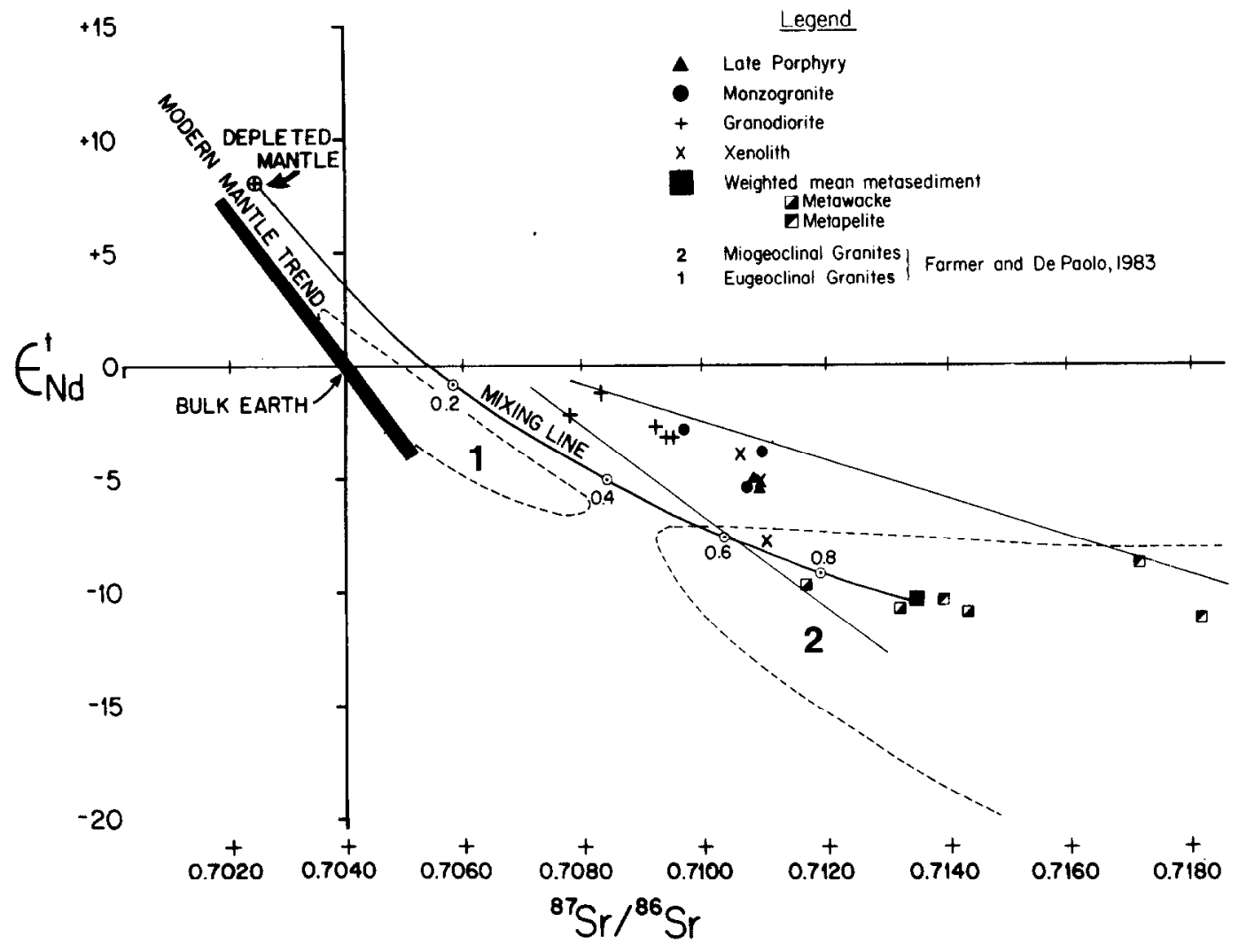

Fig. 2. Conventional $\epsilon_{\mathrm{Nd}}{ }^{87} \mathrm{Sr} /{ }^{86} \mathrm{Sr}$ diagram showing the relationships among the major rock types of the Meguma Zone of the eastern Appalachians. Points to note are that the earliest phase of the batholith (granodiorite) is most unlike the country rocks, that the trend from granodiorite through monzogranite to late porphyries could correspond to a mixing of these two components, and that there appears to be partial isotopic equilibration of the enclaves in the granodiorites. Also, a mixing line involving depleted mantle and Meguma metasedimentary rocks does not pass through the SMB array (see text for details).

$361 \mathrm{Ma})$, respectively. In addition, the granitoid rocks have higher $\epsilon_{\mathrm{Nd}}^{t}$ than the enclosing metasedimentary rocks $(-11.2$ to -8.7$)$, and the enclaves have intermediate values.

\section{Discussion}

\subsection{Relation between granitoids and country rocks: open or closed system?}

Many geochemical and isotopic data show that genetic relationships exist among the various phases of the SMB (Muecke and Clarke, 1981; Clarke and Muecke, 1985). Also, the temporal evolution of the SMB is characterized by increasing $\mathrm{SiO}_{2}, A / C N K$ and $\left({ }^{87} \mathrm{Sr} /{ }^{86} \mathrm{Sr}\right)_{\mathrm{i}}$, and decreasing $\epsilon_{\mathrm{Nd}}$ and $\sum \mathrm{REE}$ (total rare-earth elements) similar to the Criffell pluton in Scotland, U.K. (Stephens et al., 1985), all of which must be explained in a comprehensive petrogenetic model.

In their study of the $\mathrm{Sr}$ isotope geochemistry of the Meguma Zone, Clarke and Halliday (1980) concluded that there are two viable models for the Sr isotopic evolution of the SMB: (1) an open sytem in which the increase in ${ }^{87} \mathrm{Sr}$ / ${ }^{86} \mathrm{Sr}$ could be attributed to a combination of assimilation of metasedimentary country rocks coupled with fractional crystallization largely of plagioclase [now termed AFC (assimilationfractional crystallization) processes ], or (2) a closed-system model in which the increase of 


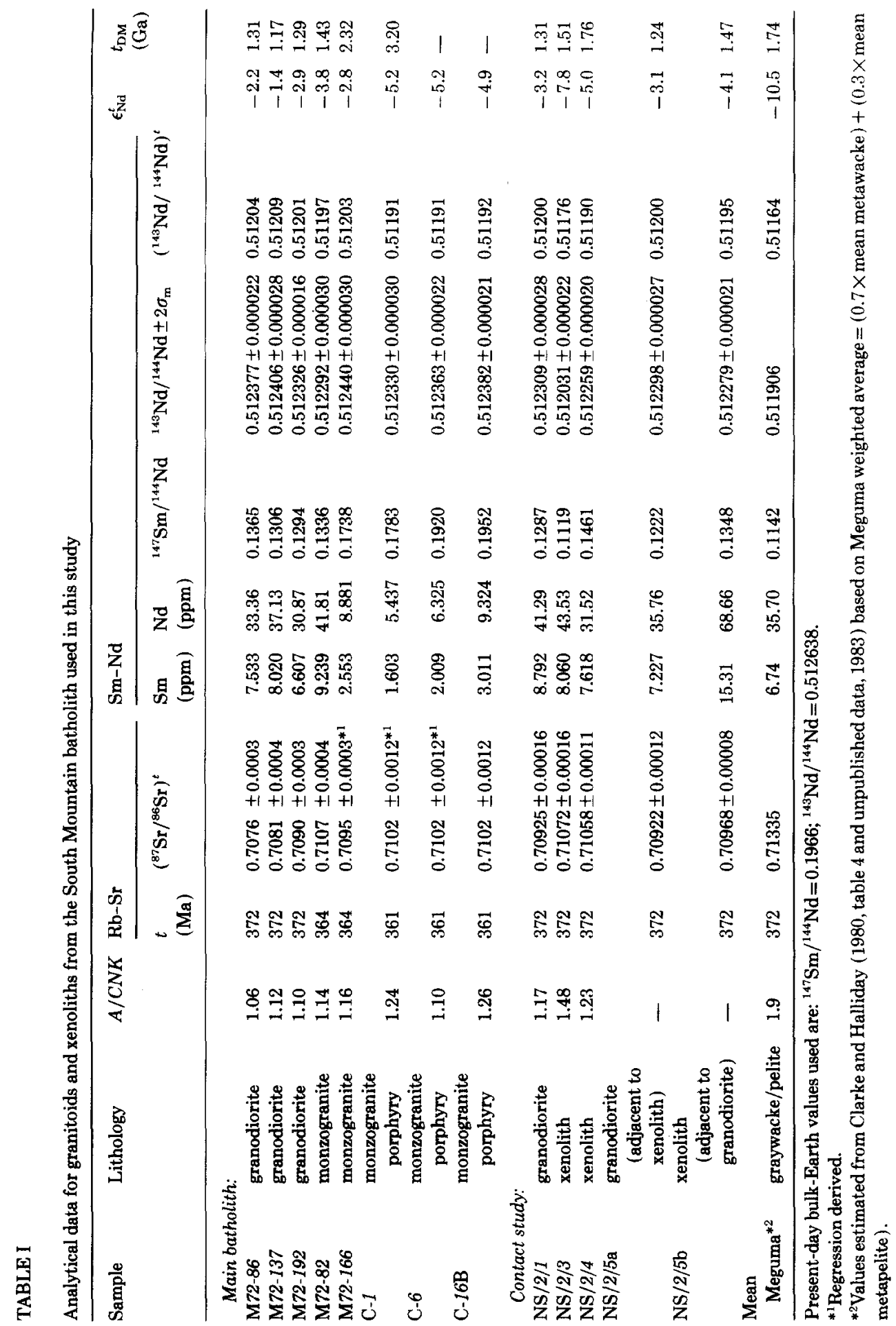


${ }^{87} \mathrm{Sr} /{ }^{86} \mathrm{Sr}$ in the magmatic complex was the result of decay of ${ }^{87} \mathrm{Rb}$ over the time required to intrude the various members of the batholith. With $\mathrm{Sr}$ isotopic data alone, it was not possible to distinguish between these models.

The Nd data presented here make possible a choice between these alternatives (Fig. 2). Although the initial $\mathrm{Sr}$ isotopic ratio could have increased from 0.7081 to 0.7102 in the $8-12 \mathrm{Ma}$ between intrusive phases through simultaneous enrichment of $\mathrm{Rb}$ and decay of ${ }^{87} \mathrm{Rb}$ (Clarke and Halliday, 1980), it is not possible to account for the decrease of $\epsilon_{\mathrm{Nd}}$ from -2 to -5 through closed-system decay of ${ }^{147} \mathrm{Sm}$ in such a short period of time (typically, the $\epsilon_{\mathrm{Nd}}$-value will decrease by only 0.1 in $10 \mathrm{Ma}$ in the granodiorites). Thus Fig. 2 suggests that the Nd-Sr isotopic variation in the SMB might be explained by varying degrees of incorporation of Meguma-like metasedimentary material.

Three other lines of evidence support the idea that Meguma material has been incorporated into the SMB:

(1) There are both magmatic and xenocrystic garnet (Allan and Clarke, 1981) and cordierite (Maillet and Clarke, 1985) in parts of the batholith.

(2) The early granodiorite phase of the SMB contains abundant xenoliths of the Meguma flyschoid rocks, ranging in size from tens of metres of centimetres, and in shape from angular to rounded, respectively. These xenoliths have minerals, textures and compositions which show that they have reacted with the granodioritic magma (Jamieson, 1974; Allan and Clarke, 1981; Woodend, 1985).

(3) Isotopic evidence from the present contact study (see Table I) appears to provide clear geochemical confirmation of the partial equilibration of the xenoliths with the magma. All samples in this subset were taken from one large outcrop on the eastern contact of the SMB. Sample NS/2/1 is a granodiorite remote from any xenoliths. Sample NS/2/5a is a granodiorite immediately adjacent to metawacke xenolith $\mathrm{NS} / 2 / 5 \mathrm{~b}$. Sample $\mathrm{NS} / 2 / 3$ is a medium- grained metawacke dominated by the assemblage quartz-biotite-plagioclase-K-feldspar and has prominent porphyroblasts of plagioclase. Sample NS/2/4 is a fine-grained metawacke hornfels with anhedral porphyroblasts of garnet. From a mineralogical and textural point of view these samples form a continuum from: granodiorite (remote from the contact) - NS/ $2 / 1-\mathrm{NS} / 2 / 5 \mathrm{a}-\mathrm{NS} / 2 / 5 \mathrm{~b}-\mathrm{NS} / 2 / 3-\mathrm{NS} / 2 /$ 4 - average Meguma metasedimentary rock, and the ${ }^{87} \mathrm{Sr} /{ }^{86} \mathrm{Sr}$ and $\epsilon_{\mathrm{Nd}}$-values are $(0.7081$, $-1.8)-(0.7092,-3.2)-(0.7092,-3.1)-$ $(0.7097,-4.1)-(0.7107,-7.8)-(0.7106$, $-5.0)-(0.7134,-10.5)$, respectively. Because the enclaves are out of isotopic equilibrium with their granitoid hosts, they cannot represent source material for the granitoids themselves, as was proposed for enclaves in the Sierra Nevada batholith (Domenick et al., 1983). Instead, they simply appear to be mineralogically, texturally, and chemically modified fragments of the country rock, assimilation of which could be responsible for part of the chemical variation observed in the SMB.

The question remains as to how much of the Meguma country rocks could have been incorporated into by the SMB magma? One approach to the problem of determining the relative inputs of Meguma, and more primitive sources in the SMB magma, is to make simple assumptions concerning the nature of the primitive material. In the extreme, if the primitive material for the SMB magma were mantle-derived basalt with $\epsilon_{\mathrm{Nd}}=+8$, and using isotopic ratios only, then:

$f\left(\mathrm{Nd}_{\mathrm{M}}\right)=\left(\epsilon_{\mathrm{NdG}}-\epsilon_{\mathrm{NdB}_{\mathrm{B}}}\right) /\left(\epsilon_{\mathrm{Nd}_{\mathrm{M}}}-\epsilon_{\mathrm{NdB}}\right)$

where $f\left(\mathrm{Nd}_{\mathrm{M}}\right)$ is the fraction of $\mathrm{Nd}$ in the granodiorite magma derived from the Meguma metasediments, $\epsilon_{\mathrm{NdG}}$ has a value of -2.2 in the granodiorites, $\epsilon_{\mathrm{Nd}_{\mathrm{M}}}$ has a value of -10.5 in the Meguma, and $\epsilon_{\mathrm{NdB}}$ has a value of +8.0 in the basalt. With these values, the fraction of $\mathrm{Nd} \mathrm{de-}$ rived from the Meguma is 0.55 . This represents a maximum because the more primitive component is unlikely to have had $\epsilon_{\mathrm{Nd}}>+8.0$. Us- 
TABLE II

Elemental concentrations and isotopic ratios used in mixing calculations to assess the origin of the granodiorite magma

\begin{tabular}{lllllr}
\hline & \multicolumn{2}{l}{ Strontium } & & \multicolumn{2}{l}{ Neodymium } \\
\cline { 2 - 3 } \cline { 6 - 7 } & $(\mathrm{ppm})$ & ${ }^{87} \mathrm{Sr} /{ }^{86} \mathrm{Sr}$ & & $(\mathrm{ppm})$ & $\epsilon_{\mathrm{Nd}}$ \\
\hline Depleted mantle & 100 & 0.7025 & & 10 & +8.0 \\
Meguma & 175 & 0.7134 & & 36 & -10.5 \\
Granodiorite & 142 & 0.7081 & & 33 & -2.2 \\
\hline
\end{tabular}

ing a similar relationship for $\left({ }^{87} \mathrm{Sr} /{ }^{86} \mathrm{Sr}\right)_{\mathrm{i}}$ and a value for a depleted mantle component of 0.7025 , the fraction of $\mathrm{Sr}$ derived from the Meguma is 0.51 . This, too, represents a maximum degree of involvement by the Meguma in the generation of the SMB magmas. More realistically, if the concentrations of $\mathrm{Nd}$ and $\mathrm{Sr}$ are also taken into account and standard mixing equations are used (Faure, 1986; Table II), then Fig. 2 shows that the mixing line between depleted mantle and Meguma does not pass through the SMB array. The implication of this calculation is that if both depleted mantle and Meguma components are involved in the SMB, then there must be at least one more component or process, as yet unidentified. Indeed, there are many possible variations in the isotopic compositions of the hypothetical mantle component, and/or the evolutionary processes (e.g., AFC; DePaolo, 1981), to achieve a better fit to the SMB data.

It is now clear, from the strong decrease in $\epsilon_{\mathrm{Nd}}$ in the cotectic granitic rocks of the SMB, that involvement of Meguma country rocks, either as one contributing source material or as contaminant, has occurred. The presence of partially digested xenoliths, the presence of partial melting in some xenoliths, and possibly the increase of $A / C N K$ with fractionation, all point to an open system where the country rocks are involved in the chemical evolution of the batholith. Superimposed on this variation, caused by two or more source components, are both crystal-liquid fractionation (McKenzie and Clarke, 1975), and the evolution of a sep- arate vapour phase (Muecke and Clarke, 1981) as important causes of the remaining chemical variation in the batholith. These processes have recently been reviewed (Clarke and Muecke, 1985; Clarke and Chatterjee, 1988).

\subsection{Source of the granodiorite magma}

Despite uncertainties concerning the relative inputs to the SMB as a whole, there are several constraints on the source of the SMB granodioritic magma:

(1) As demonstrated above, the host Meguma metasedimentary rocks represent only one of the components in the granodiorite magma.

(2) The granodiorite has generally high $\delta^{18} \mathrm{O}$ values $(+10$ to $+12 \%$ SMOW; Longstaffe et al., 1980) and $A / C N K$, characteristics more readily acquired from low-grade metasedimentary rocks than from mantle-derived materials.

(3) The granodiorite is relatively uniform in composition. It may thus represent derivation from a homogeneous source, or if it is a hybrid, it represents a high degree of homogenization.

(4) High temperatures are required to create granodiorite magmas. If there were mantle material as input to the $\mathrm{SMB}$, then a source of heat to melt the crustal component is not a problem. Mafic intrusions that could be genetically related to the SMB have not been found within the batholith, but do occur around its periphery. These are volumetrically minor dykes and plugs in southwestern Nova Scotia (de Albuquerque, 1977; Rogers, 1985; Douma, 1988), but there are more important gabbroic breccia pipes spatially associated with the nearby Liscomb Complex (Giles and Chatterjee, 1986). These may yet be shown to be extremely important in the magmatic evolution of the Meguma Zone, but at present the evidence is only embryonic. Alternatively, if the other component in the SMR is solely crustal in composition and energy, then the heat necessary to produce the granodioritic magma of the SMB would require considerable overthrusting, most likely during the Acadian deformation.

Given these constraints, we believe that the 
SMB granodiorite was probably derived from a deeper crustal source that was largely metasedimentary, but which contained a greater proportion of material with either younger crustal residence ages, or higher $\mathrm{Sm} / \mathrm{Nd}$ ratios (less fractionated REE patterns), than are found in the Meguma metasediments (see next section). This could happen in one of two different ways: (1) the metasediments of the Meguma Zone represent an inverted time sequence where the younger rocks of a former crustal segment (the African Shield?; Clarke and Halliday, 1985) were eroded first and buried beneath older materials eroded later from the same, or another, source similar to the cases discussed by Hamilton et al. (1983) and Allègre and Rousseau (1984), or (2) there is an unrecognized tectonic boundary in the Meguma Zone between the observed Meguma Group flyschoid metasediments, and unknown crust beneath. If the latter case, there may be a link between possible "thin-skin tectonics", proposed here and elsewhere in the Appalachians (Cook et al., 1979; Brown et al., 1983; Rast, 1984; Williams, 1984 ), and magma generation, where overriding by the Meguma Group may have been sufficient to cause the raising of isotherms and melting of the underlying crustal material. Whatever the nature of the crustal source material, the high $\epsilon_{\mathrm{Nd}}$-values and relatively high ${ }^{87} \mathrm{Sr} /{ }^{86} \mathrm{Sr}$ ratios rule out a significant contribution from ancient granulites (Farmer and DePaolo, 1983; Harmon et al., 1984; Hensel et al., 1985) such as Grenvillian basement (McCulloch and Wasserburg, 1978) that crops out elsewhere in the Appalachians but is not known to occur in the Meguma Zone. This deduction concerning the absence of granulites agrees with both seismic profiles (Dainty et al., 1966) and depositional models (Schenk, 1970, 1971) for the Meguma, neither of which have allowed for a lower-crustal granulite facies zone. With the present isotopic data, it is not possible to distinguish between the inverted and thinskin crustal models for the stratigraphy of the Meguma Zone.

\subsection{Model ages of granitoids, xenoliths and country rocks}

Fig. 3 shows a conventional $\epsilon_{\mathrm{Nd}^{-}}-t$ plot for all analyzed rocks from the Meguma Zone. The Meguma metasedimentary rocks show a welldefined evolutionary history with $\epsilon_{\mathrm{Nd}}^{t}(t=372$ $\mathrm{Ma}$ values from -11.2 to -8.7 and $t_{\mathrm{DM}}=1.74 \pm 0.1 \mathrm{Ga}$. All the granodiorites are similarly constrained to $\epsilon_{\mathrm{Nd}}^{t}(t=372 \mathrm{Ma})$ values from -2.9 to -1.4 and $t_{\mathrm{DM}}=1.26 \pm 0.06 \mathrm{Ga}$. However, the enclaves show wide variations in their ${ }^{147} \mathrm{Sm} /{ }^{144} \mathrm{Nd}$ ratios probably related to fractionation of $\mathrm{Sm}$ and $\mathrm{Nd}$ during partial melting, and this is reflected in a wide variation in $t_{\mathrm{DM}}$ from 1.47 to $1.76 \mathrm{Ga}$ (Fig. 3), the latter value being similar to the mean Meguma host rocks.

The late monzogranites and monzogranite porphyries, i.e. those probably resulting from fractional crystallization and significant amounts of assimilation of Meguma country rocks, are the most variable of the rock types shown on Fig. 3. Their $\epsilon_{\mathrm{Nd}}$-values are displaced toward those of the country rock, but their ${ }^{147} \mathrm{Sm} /{ }^{144} \mathrm{Nd}$ ratios are very high (Table I). Muecke and Clarke (1981) showed that neither the decrease in $\Sigma$ REE's, nor the decrease in $\mathrm{La} /$ $\mathrm{Yb}$ ratios, in the monzogranites can be explained by known fractional crystallization processes or bulk contamination by the Meguma. They concluded that late-stage hydrothermal fluids were responsible for these changes, a process which could change $\mathrm{Sm} / \mathrm{Nd}$ $\left({ }^{147} \mathrm{Sm} /{ }^{144} \mathrm{Nd}\right.$ ), but not affect ${ }^{143} \mathrm{Nd} /{ }^{144} \mathrm{Nd}$. However, recent separations of monazite from some of the monzogranites (C. Harper, pers. commun., 1986) may yet show an increased importance for the role of fractional crystallization in the SMB.

\subsection{I- and S-type granites and the restite model}

It has been demonstrated here that there are at least two components in the SMB. One of 


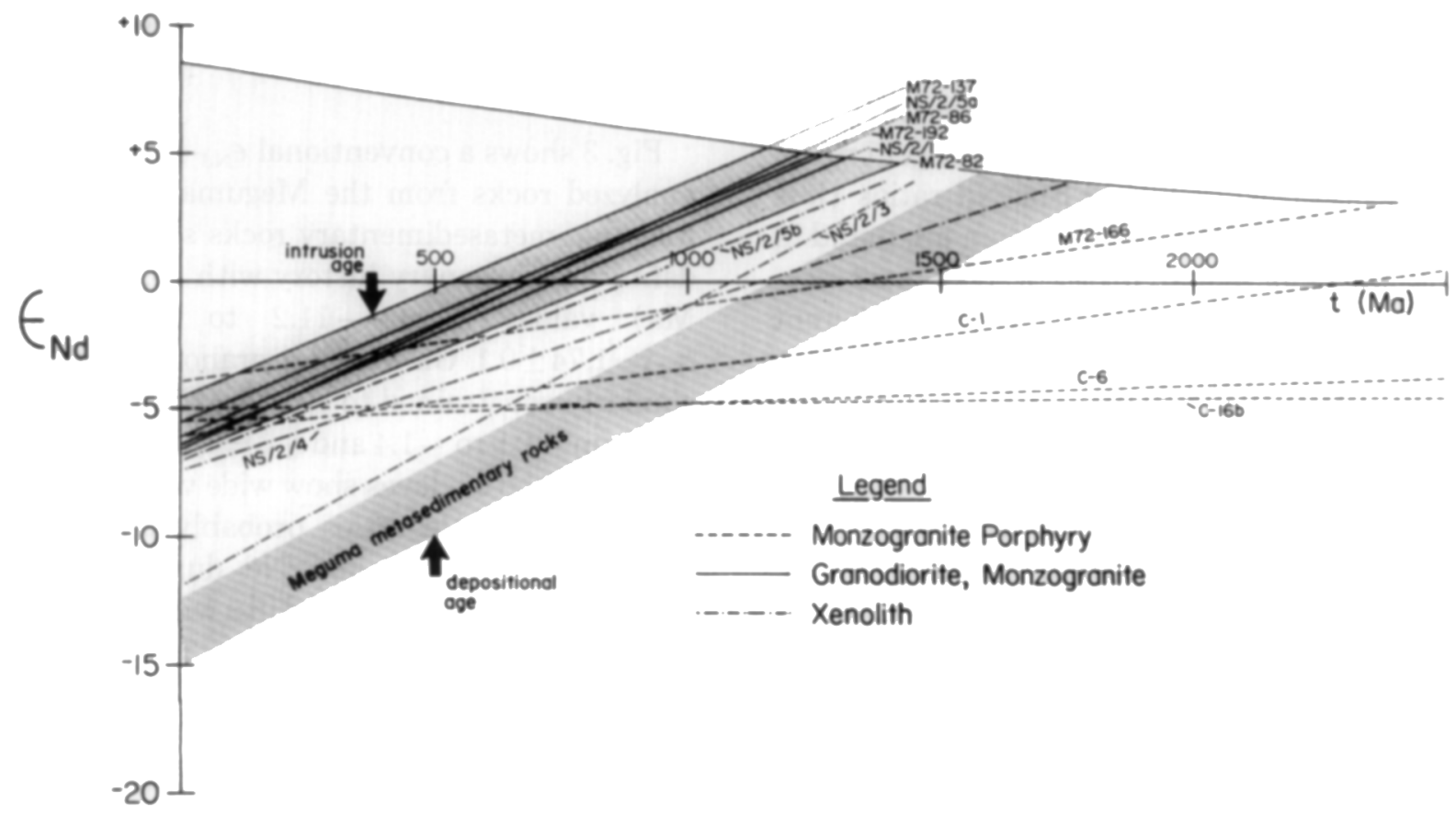

Fig. 3. A plot of $\epsilon_{\mathrm{Nd}^{-}}-t$ showing all samples of granitoids, country rocks and xenoliths from the Meguma Zone. Depleted mantle curve is after Farmer and DePaolo (1983). All of the granodiorites define a restricted zone of variation with $t_{\mathrm{DM}}=1.26 \pm 0.06$ $\mathrm{Ga}$. The country rocks of the Meguma Group (Clarke and Halliday, 1985) have $t_{\mathrm{DM}}=1.74 \pm 0.1 \mathrm{Ga}$. Other granitoids in the batholith and one enclave behave erratically (see text for interpretation).

these components is the highly peraluminous $(A / C N K=1.29-3.58)$ metasediments of the Meguma Group; the other, if mantle-derived, might even have been metaluminous and, if so, the I-S genetic classification for such hybrid magmas is inappropriate. Secondly, because the partial isotopic equilibration of the xenoliths with their granitoid hosts has been clearly demonstrated, and supports the mineralogical, textural and chemical equilibration already described, their link with the country rocks is clear and restite separation in the SMB is not an identifiable process given our data. Clarke and Muecke (1985) have used many other lines of evidence to question the application of the restite model to the SMB, and Wall et al. (1987) have discussed the general problem of restite separation extensively.

\section{Conclusions}

Many physical and chemical processes have operated to account for the observed geochemical variation in the South Mountain batholith (Clarke and Chatterjee, 1988). The most significant results of the present study are:

(1) The Nd isotopic data provide the first clear chemical evidence that involvement of country rock is responsible for some of the chemical diversity in the batholith. The general absence of metasedimentary enclaves from the later monzogranites and porphyries could be explained alternatively by the failure of the later monzogranite differentiates to come in contact with the metasedimentary rocks (unlikely, in view of their low $\epsilon_{\mathrm{Nd}}$-values), by partial assimilation and complete gravity settling of the 
xenoliths, or even by effectively complete assimilation of the foreign material.

(2) In addition to assimilation, other processes such as fractional crystallization are required to account for much of the major- and trace-element variation, including $\mathrm{Rb}$ and $\mathrm{Sr}$, and late-stage fluid phases may explain the variation in REE's, including $\mathrm{Sm}$ and $\mathrm{Nd}$, as well as $\mathrm{Li}$ and some of the economic elements such as $\mathrm{Sn}-\mathrm{W}-\mathrm{Cu}-\mathrm{Mo}-\mathrm{U}$ (Strong and Taylor, 1988). Each process undeniably has had an effect on every chemical constituent in the batholith, although it may not yet be quantified, and in some cases two different processes may strongly affect a single parameter, e.g. $A / C N K$ will be very sensitive to both assimilation and the action of fluid phases, but its variation is severely limited during crystal-melt fractionation (Zen, 1986). So far, our geochemical tools are not sufficiently good to resolve the relative effects of such overlapping processes.

(3) At present, we believe that a deeper crustal source for the SMB best explains its bulk chemical and isotopic characteristics, although the implications are that this source has a younger residence age (inverted crustal residence stratigraphy), or higher $\mathrm{Sm} / \mathrm{Nd}$ ratios (less fractionated REE patterns), than the metasedimentary rocks of the Meguma Group exposed at the surface. However, because of increasing evidence for a spatial association of some peraluminous granites with mafic intrusive rocks in the Meguma Zone, another possible origin for the SMB is the mixing of mantle melts and upper-crustal materials, the implications of which are that the mixing process is extremely thorough, and that the SMB contains large fractions of mantle-derived $\mathrm{Nd}$ and Sr.

\section{Acknowledgements}

The first author whishes to express gratitude to the Natural Sciences and Engineering Research Council, Canada for financial support of this research project, to Dr. C. Beaumont for drawing attention to some additional tectonic implications of this study, and to Drs. K. Bell and W.R. Premo for helpful reviews of an early version of this paper.

\section{References}

Allan, B.D. and Clarke, D.B., 1981. Occurrence and origin of garnets in the South Mountain batholith, Nova Scotia. Can. Mineral., 19: 19-24.

Allègre, C.J. and Rousseau, D., 1984. The growth of the continents through geological time studied by Nd isotope analysis of shales. Earth Planet. Sci. Lett., 67: 1934.

Brown, L., Ando, C., Klemperer, S., Oliver, J., Kaufman, S., Czuchra, B., Walsh, T. and Isachsen, Y.W., 1983. Adirondack-Appalachian crustal structure: The COCORP northeast traverse. Geol. Soc. Am. Bull., 94: 11731184.

Chappell, B.W., 1984. Source rocks of I- and S-type granites in the Lachlan fold belt, southeastern Australia. Philos. Trans. R. Soc. London, Ser. A, 310: 693-707.

Clarke, D.B. and Chatterjee, A.K., 1988. Physical and chemical processes in the South Mountain batholith, Nova Scotia. In: R.P. Taylor (Editor), Recent Advances in the Geology of Granite-Related Mineral Deposits. Can. Inst. Min. Metall. Spec. Vol. 39 (in press).

Clarke, D.B. and Halliday, A.N., 1980. Strontium isotope geology of the South Mountain batholith, Nova Scotia. Geochim. Cosmochim. Acta., 44: 1045-1058.

Clarke, D.B. and Halliday, A.N., 1985. Sm/Nd isotopic investigation of the age and origin of the Meguma Zone metasedimentary rocks. Can. J. Earth Sci., 22: 102-107.

Clarke, D.B. and Muecke, G.K., 1985. Review of the petrochemistry and origin of the South Mountain batholith and associated plutons, Nova Scotia, Canada. In: The Institution of Mining and Metallurgy High Heat Production (HHP) Granites, Hydrothermal Circulation and Ore Genesis. Can. Inst. Min. Metall., Montreal, Que., pp. 41-54.

Cook, F.A., Aldbaugh, D.S., Bronw, L.D., Kaufman, S., Oliver, J.E. and Hatcher, R., 1979. Thin-skinned tectonics in the crystalline southern Appalachians: COCORP seismic-reflection profiling of the Blue Ridge and Piedmont. Geology, 7: 563-567.

Dainty, A.M., Keen, C.E., Keen, M.J. and Blanchard, J.E., 1966. Review of geophysical evidence on crust upper mantle structure on the eastern seaboard of Canada. Am. Geophys. Union Monogr., 10: 349-469.

De Albuquerque, C.A.R., 1977. Geochemistry of the tonalitic and granitic rocks of the Nova Scotia southern plutons. Geochim. Cosmochim. Acta, 41: 1-13.

DePaolo, D.J., 1981. Trace element and isotopic effects of combined wallrock assimilation and fractional crystallization. Earth Planet. Sci. Lett., 53: 189-202. 
Domenick, M.A., Kistler, R.W., Dodge, F.C.W. and Tatsumoto, M., 1983. Nd and Sr isotopic study of crustal and mantle inclusions from the Sierra Nevada and implications for batholith petrogenesis. Geol. Soc. An. Bull., 94: 713-719.

Douma, S.L., 1988. The Mineralogy, Petrology and Geochemistry of the Port Mouton Pluton, Nova Scotia. M.Sc. Thesis, Dalhousie University, Halifax, N.S. (unpublished).

Farmer, G.L. and De Paolo, D.J., 1983. Origin of Mesozoic and Tertiary granite in the western United States and implications for pre-Mesozoic crustal structure, 1 . Nd and $\mathrm{Sr}$ isotopic studies in the geocline of the northern Great Basin. J. Geophys. Res., 88: 3379-3401.

Faure, G., 1986. Principles of Isotope Geology. Wiley, New York, N.Y., 2nd ed., 589 pp.

Giles, P.S. and Chatterjee, A.K., 1986. The peraluminous granites of the Liscomb complex. N.S., Dep. Mines Energy, Info. Ser., 12: 83-89.

Halliday, A.N., Fallick, A.E., Hutchinson, J. and Hildreth, W., 1984. A Nd, Sr and O isotopic investigation in the causes of chemical and isotopic zonation in the Bishop Tuff, California. Earth Planet. Sci. Lett., 68: 379-391.

Hamilton, P.J., O'Nions, R.K., Bridgwater, D. and Nutman, A., 1983. Sm-Nd studies of Archaean metasediments and metavolcanics from West Greenland and their implications for the Earth's early history. Earth Planet. Sci. Lett., 62: 263-272.

Harmon, R.S., Halliday, A.N., Clayburn, J.A.P. and Stephens, W.E., 1984. Chemical and isotopic systematics of the Caledonian instrusions of Scotland and northern Fngland; a guide to magma source region and magmacrust interaction. Philos. Trans. R. Soc. London, Ser. A, 310: 707-742.

Hensel, H.-D., McCulloch, M.T. and Chappell, B.W., 1985. The New England batholith: constraints on its derivation from $\mathrm{Nd}$ and $\mathrm{Sr}$ isotopic studies of granitoids and country rocks. Geochim. Cosmochim. Acta, 49: 369-384.

Jamieson, R.A., 1974. The contact of the South Mountain batholith near Mount Uniacke, Nova Scotia. Hons. BSc. Thesis, Dalhousie University, Halifax, N.S., 52 pp.

Keppie, J.D. and Poole, W.H., 1984. Symposium: Geology of the Meguma terrane of Nova Scotia. Geol. Soc. Am. Abstr. Prog., 16: 1.

Longstaffe, F.J., Smith, T.E. and Muehlenbachs, K., 1980. Oxygen isotope evidence for the genesis of Upper Paleozoic granitoids from southwestern Nova Scotia. Can. J. Earth Sci., 17: 132-141.

Maillet, L.A. and Clarke, D.B., 1985. Cordierite in the peraluminous granites of the Meguma Zone, Nova Scotia, Canada. Mineral. Mag., 49: 695-702.

McCulloch, M.T. and Wasserburg, G.T., 1978. Sm-Nd and $\mathrm{Rb}$-Sr chronology of continental crust formation. Science, 200: 1003-1011.

McKenzie, C.B. and Clarke, D.B., 1975. Petrology of the
South Mountain batholith, Nova Scotia. Can. J. Earth Sci., 12: 1209-1218.

Muecke, G.K. and Clarke, D.B., 1981. Geochemical evolution of the South Mountain batholith, Nova Scotia: rareearth-element evidence. Can. Mineral., 19: 133-145.

Rast, N., 1984. Alleghenian orogeny in eastern North America. In: D.H.W. Hutton and D.J. Fanderson (Editors), Variscan Tectonics of the North Atlantic Region. Blackwell Scientific Publ., London, pp. 197-217.

Reynolds, P.H., Zentilli, M. and Muecke, G.K., 1981. KAr and ${ }^{40} \mathrm{Ar} /{ }^{39} \mathrm{Ar}$ geochronology of granitoid rocks from southern Nova Scotia: its bearing on the geological evolution of the Meguma Zone of the Appalachians. Can. J. Earth Sci., 18: 386-394.

Reynolds, P.H., Elias, P., Muecke, G.K. and Grist, A.M., 1987. Thermal history of the southwestern Meguma Zone, Nova Scotia, fron an ${ }^{40} \mathrm{Ar} /{ }^{39} \mathrm{Ar}$ and fission track dating study of intrusive rocks. Can. J. Earth Sci., 24: 1952-1965.

Rogers, H.D., 1985. Granitoid rocks of Shelburne County and eastern Yarmouth County, Nova Scotia. N.S., Dep. Mines Energy, Rep., 85-3: 121-130.

Schenk, P.E., 1970. Regional variations of the flysch-like Meguma Group (Lower Paleozoic) of Nova Scotia com pared to recent sedimentation off the Scotian Shelf. Geol. Assoc. Can., Spec. Publ., 7: 127-153.

Schenk, P.E., 1971. Southeastern Atlantic Canada, northwestern Africa, and continental drift. Can. J. Earth Sci., 8: $1128-1152$.

Schenk, P.E., 1978. Synthesis of the Canadian Appalachians. Geol. Surv. Can. Pap., 78-13: 113-136.

Stephens, W.E., Whitley, J.E., Thirlwall, M.T. and Halliday, A.N., 1985. The Criffell zoned pluton: correlated behaviour of rare earth element abundances with isotopic systems. Contrib. Mineral. Petrol., 89: 226-238.

Strong, D.F. and Taylor, R.P., 1988. Granite-related mineral deposits: a model. In: R.P. Taylor (Editor), Recent Advances in the Geology of Granite-Related Mineral Deposits. Can. Inst. Min. Metall., Spec. Vol. 39 (in press).

Wall, V.J., Clemens, J.D. and Clarke, D.B., 1987. Models for granitoid evolution and source compositions. J. Geul., 95: 731-749.

Williams, H., 1984. Miogeoclines and suspect terranes of the Caledonian-Appalachian orogen: tectonic patterns in the North Atlantic region. Can. J. Earth Sci., 21: 887901.

Woodend, S.L., 1985. Enclaves in granitoid massifs - origin and assimilation with special regard to two enclaves from the South Mountain batholith, Nova Scotia. Dalhousie Univ., Halifax, N.S., Intern. Rep., 84 pp.

Zen, E-an, 1986. Aluminum enrichment in silicate melts by fractional crystallization: some mineralogic and petrographic constraints. J. Petrol., 27: 1095-1117. 